\title{
PEMBERIAN PUPUK AB MIX PADA TANAMAN PAKCOY PUTIH (Brassica rapa L.) DENGAN SISTEM HIDROPONIK RAKIT APUNG
}

\author{
The Giving AB Mix Fertilizer on White Pakcoy (Brassica rapa L.) Using Floating \\ Hydroponic System
}

\author{
Muhammad Fuad Syah, Ardian, dan Arnis En Yulia \\ Program Studi Agroteknologi, Fakultas Pertanian, Universitas Riau \\ Kampus Bina Widya km 12,5 ,Pekanbaru \\ Email: muhammadfuadsyah@gmail.com HP : 085274748714 \\ [Diterima: Februari 2021; Disetujui: April 2021]
}

\begin{abstract}
This research aims to obtain the proper nutrient concentration and the best nutrient concentration and increase the growth and yield of pakcoy through the floating hydroponic system. The research was conducted in the Experimental Farm of the Faculty of Agriculture, University of Riau from October to November 2019. The research used a non-factorial completely randomized design (CRD), consisting of 5 treatments and 4 replications. The given treatment was the nutrient concentration of AB Mix consisting of 5 levels: AB Mix 1000 ppm, AB Mix 1200 ppm, AB Mix 1400 ppm, AB Mix 1600 ppm, and AB Mix 1800 ppm. The parameters observed were plant height, leaf number, leaf area, root volume, plant fresh weight, and worthy weight consumption. The result showed that all the given treatments did not have significant towards all parameters. The concentration of $1000 \mathrm{ppm}$ is the best concentration of some else, because more efficient, economic and saves the solution uses of nutrien in concentration. Based on the results of a study that has been conducted, to gain growth and the results of white pakcoy plant are both hydroponic can usea concentration of $\mathrm{AB}$ Mix 1000 ppm.
\end{abstract}

Keyword: AB Mix, Pakcoy, Hydroponic

\begin{abstract}
ABSTRAK
Penelitian ini bertujuan untuk mendapatkan konsentrasi hara yang tepat dan konsentrasi hara terbaik serta mampu meningkatkan pertumbuhan dan hasil tanaman pakcoy melalui sistem hidroponik rakit apung. Penelitian dilaksanakan di Rumah Kebun Percobaan Fakultas Pertanian Universitas Riau pada bulan Oktober sampai November 2019. Penelitian menggunakan Rancangan Acak Lengkap (RAL) non-faktorial yang terdiri dari 5 perlakuan dan 4 ulangan. Adapun perlakuan yang diberikan adalah konsentrasi pupuk $\mathrm{AB}$ Mix yang terdiri dari 5 taraf perlakuan yaitu, $\mathrm{AB}$ Mix $1000 \mathrm{ppm}, \mathrm{AB}$ Mix 1200 ppm, AB Mix 1400 ppm, AB Mix 1600 ppm, AB Mix 1800 ppm. Parameter yang diamati adalah tinggi tanaman, jumlah daun, luas daun, volume akar, berat segar tanaman dan berat layak konsumsi. Hasil penelitian menunjukkan bahwa semua perlakuan yang diberikan tidak menunjukkan pengaruh nyata terhadap semua paramater pengamatan. Konsentrasi AB Mix 1000 ppm merupakan konsentrasi terbaik dari beberapa konsentrasi yang diberikan disebabkan lebih efisien, ekonomis dan menghemat pemakaian larutan nutrisi. Berdasarkan hasil penelitian yang telah dilakukan, untuk mendapatkan pertumbuhan dan hasil tanaman pakcoy putih yang baik dibudidayakan secara hidroponik dapat menggunakan konsentrasi nutrisi AB Mix 1000 ppm.
\end{abstract}

Kata kunci: AB Mix, Pakcoy, Hidroponik

\section{PENDAHULUAN}

Pakcoy (Brassica rapa L.) adalah salah satu sayuran daun yang banyak disukai oleh masyarakat di indonesia, sehingga sangat perlu untuk dikembangkan. Sayuran pakcoy mengandung gizi yang cukup tinggi, yaitu kalori, protein, lemak, karbohidrat, serat, $\mathrm{Ca}$, $\mathrm{Mg}, \mathrm{P}, \mathrm{Fe}$, vitamin $\mathrm{A}$, vitamin $\mathrm{B}$, Vitamin $\mathrm{C}$, Vitamin E dan Vitamin K. Kebutuhan masyarakat akan sayuran semakin meningkat setiap waktunya. Peningkatan antusiasme 
masyarakat dalam mengkonsumsi sayuran yang berkualitas sehingga diperlukan upaya yang optimal dalam budidaya tanaman. Salah satu cara untuk menghasilkan produk yang higenis dan bergizi tinggi yaitu dengan budidaya secara hidroponik.

Hidroponik adalah sistem budidaya yang memanfaatkan air atau daya air, tanpa adanya penggunaan tanah. Salah satu sistem yang dapat digunakan untuk budidaya secara hidroponik yaitu sistem rakit apung (floating hidroponic system). Menurut Maghfoer, Roedy dan Misky (2015), sitem hidroponik rakit apung (floating hidroponic system) merupakan suatu budidaya tanaman dengan cara menanam tanaman pada lubang box styrofoam hidroponik yang mengapung $\mathrm{di}$ atas permukaan larutan nutisi dalam bak penampung dengan akar menyentuh air.

Faktor penting yang menentukan keberhasilan budidaya hidroponik adalah larutan nutrisi. Kebutuhan nutrisi yang terpenuhi bagi tanaman dapat membuat pertumbuhan menjadi lebih optimal. Secara umum hidroponik memerlukan unsur hara yang lengkap dan mengandung unsur hara esensial yang terdiri dari makro dan mikro. Banyak pupuk komplek yang tersedia saat ini, salah satunya adalah $\mathrm{AB}$ Mix yang sudah diformulasikan khusus untuk hidroponik. Larutan stok A yang berisi unsur hara makro yaitu Nitrogen (N), Fosfor (P), Kalium (K), Kalsium (Ca), Magnesium (Mg), dan Sulfur (S) serta stok B yang berisi hara mikro yaitu Besi (Fe), Mangan (Mn), Boron (B), Tembaga $(\mathrm{Cu})$, Zeng (Zn) dan Molibdenum (Mo) (Nugraha, 2014).

Pemberian beberapa konsentrasi pupuk AB Mix mampu meningkatkan pertumbuhan tanaman budidaya. Hasil penelitian Sundari et al. (2016), pemberian $\mathrm{AB}$ Mix berpengaruh sangat nyata terhadap pertumbuhan dan hasil panen pakcoy. Perlakuan AB Mix 1.800 ppm memberikan hasil tertinggi terhadap bobot pertanaman.

Berdasarkan hal tersebut peneliti telah melaksanakan penelitian dengan judul "Pemberian Pupuk AB Mix pada Tanaman Pakcoy Putih (Brassica rapa L.) dengan Sistem Hidroponik Rakit Apung". Penelitian ini bertujuan untuk mengetahui pengaruh dari beberapa konsentrasi pupuk $\mathrm{AB}$ Mix dan menentukan konsentrasi yang tepat untuk pertumbuhan dan hasil tanaman pakcoy putih (Brassica rapa L.) dengan sistem hidroponik rakit apung.

\section{METODOLOGI PENELITIAN}

Penelitian dilaksanakan di Rumah Kasa Kebun Percobaan Fakultas Pertanian Kampus Bina Widya, Universitas Riau, Kota Pekanbaru, mulai dari bulan Oktober sampai November 2019.

Bahan yang digunakan adalah tanaman pakcoy varietas white, pupuk $\mathrm{AB}$ Mix, box styrofoam, plastik, rockwool. Alat yang digunakan adalah gelas takar, botol, $\mathrm{pH}$ meter, TDS meter, netpot, mistar, cutter, tray, pinset, ember, jerigen.

Penelitian ini dilaksanakan secara eksperimen dengan menggunakan rancangan acak lengkap (RAL) yang terdiri dari 5 perlakuan dan 4 ulangan. Perlakuan dan ulangan tersebut terdapat 20 unit percobaan. Setiap unit percobaan terdiri dari 6 tanaman, sehingga jumlah tanaman dalam penelitian ini adalah 120 tanaman. Perlakuan yang diberikan adalah konsentrasi pupuk $\mathrm{AB}$ Mix (M) yang terdiri dari 5 taraf perlakuan, antara lain: $\mathrm{M} 1=$ AB Mix 1000 ppm, M2= AB Mix 1200 ppm, M3= AB Mix 1400 ppm, M4= AB Mix 1600 ppm, M5= AB Mix 1800 ppm.

Parameter pengamatan terdiri dari tinggi tanaman, jumlah daun, luas daun, volume akar, berat segar tanaman dan berat layak konsumsi. Data yang diperoleh dianalisis secara statistik dengan menggunakan analisis ragam (ANOVA) dan dilanjutkan dengan uji jarak berganda Duncan pada taraf 5\%.

\section{HASIL DAN PEMBAHASAN}

\section{Tinggi Tanaman dan Jumlah Daun}

Hasil sidik ragam menunjukkan bahwa pemberian beberapa konsentrasi $\mathrm{AB}$ Mix berpengaruh tidak nyata terhadap tinggi dan jumlah daun pada tanaman pakcoy putih. Rerata tinggi dan jumlah daun pada tanaman setelah diuji lanjut dapat dilihat pada Tabel 1 .

Tabel 1 menunjukan bahwa pemberian berbagai nutrisi $\mathrm{AB}$ Mix pada parameter tinggi dan jumlah daun tanaman pakcoy putih antar perlakuannya berbeda tidak nyata. 
Tabel 1. Tinggi Tanaman (cm) dan Jumlah Daun (helai) Tanaman Pakcoy Putih pada Pemberian Berbagai Konsentrasi Pupuk AB Mix.

\begin{tabular}{ccc}
\hline Konsentrasi Pupuk AB Mix $(\mathrm{ppm})$ & Tinggi Tanaman & Jumlah daun \\
\hline 1000 & $30,43 \mathrm{a}$ & $11,17 \mathrm{a}$ \\
1200 & $32,12 \mathrm{a}$ & $10,38 \mathrm{a}$ \\
1400 & $30,43 \mathrm{a}$ & $10,88 \mathrm{a}$ \\
1600 & $31,64 \mathrm{a}$ & $10,71 \mathrm{a}$ \\
1800 & $31,90 \mathrm{a}$ & $11,38 \mathrm{a}$ \\
\hline
\end{tabular}

Angka-angka pada kolom yang diikuti oleh huruf kecil yang tidak sama berbeda nyata menurut uji jarak berganda Duncan pada taraf $5 \%$

\section{Luas Daun dan Volume Akar}

Hasil sidik ragam menunjukkan bahwa pemberian beberapa konsentrasi $\mathrm{AB}$ Mix berpengaruh tidak nyata terhadap luas daun dan volume akar tanaman pakcoy putih. Rerata luas daun dan volume akar tanaman setelah diuji lanjut dapat dilihat pada Tabel 2 .

Tabel 2. Luas Daun $\left(\mathrm{cm}^{2}\right)$ dan Volume Akar (ml) Tanaman Pakcoy Putih pada Pemberian Berbagai Konsentrasi Pupuk AB Mix.

\begin{tabular}{ccc}
\hline Konsentrasi Pupuk AB Mix $(\mathrm{ppm})$ & Luas Daun & Volume Akar \\
\hline 1000 & $56,54 \mathrm{a}$ & $112,00 \mathrm{a}$ \\
1200 & $62,93 \mathrm{a}$ & $111,50 \mathrm{a}$ \\
1400 & $60,45 \mathrm{a}$ & $109,83 \mathrm{a}$ \\
1600 & $64,12 \mathrm{a}$ & $11,84 \mathrm{a}$ \\
1800 & $59,46 \mathrm{a}$ & $111,50 \mathrm{a}$ \\
\hline
\end{tabular}

Angka-angka pada kolom yang diikuti oleh huruf kecil yang tidak sama berbeda nyata menurut uji jarak berganda Duncan pada taraf $5 \%$

Tabel 2 menunjukan bahwa pemberian berbagai nutrisi $\mathrm{AB}$ Mix pada parameter luas daun dan volume akar tanaman pakcoy putih antar perlakuannya berbeda tidak nyata.

\section{Berat Segar Tanaman dan Berat Layak Konsumsi}

Tabel 3. Berat Segar Tanaman (g) dan Berat Layak Konsumsi (g) Tanaman Pakcoy Putih pada Pemberian Berbagai Konsentrasi Pupuk AB Mix.

\begin{tabular}{ccc}
\hline Konsentrasi Pupuk AB Mix $(\mathrm{ppm})$ & Berat Segar Tanaman & Berat Layak Konsumsi \\
\hline 1000 & $120,50 \mathrm{a}$ & $108,33 \mathrm{a}$ \\
1200 & $120,67 \mathrm{a}$ & $108,21 \mathrm{a}$ \\
1400 & $116,08 \mathrm{a}$ & $104,17 \mathrm{a}$ \\
1600 & $144,21 \mathrm{a}$ & $129,21 \mathrm{a}$ \\
1800 & $108,25 \mathrm{a}$ & $93,00 \mathrm{a}$ \\
\hline
\end{tabular}

$\overline{\text { Angka-angka pada kolom yang diikuti oleh huruf kecil yang tidak sama berbeda nyata menurut uji jarak berganda Duncan }}$ pada taraf $5 \%$

Tabel 3 menunjukan bahwa pemberian berbagai nutrisi $\mathrm{AB}$ Mix pada parameter berat segar dan berat layak konsumsi tanaman pakcoy antar perlakuannya berbeda tidak nyata.

Hasil penelitian menunjukkan bahwa penggunaan pupuk $\mathrm{AB}$ Mix dimulai dari konsentrasi terendah $1000 \mathrm{ppm}$ hingga konsentrasi yang tertinggi $1800 \mathrm{ppm}$ pada tanaman pakcoy putih memberikan hasil yang berbeda tidak nyata pada parameter tinggi tanaman dan jumlah daun (Tabel 1), luas daun
Hasil sidik ragam menunjukkan bahwa pemberian beberapa konsentrasi $\mathrm{AB}$ Mix berpengaruh tidak nyata terhadap berat segar tanaman dan berat layak konsumsi tanaman pakcoy putih. Rerata berat segar dan berat layak konsumsi tanaman setelah diuji lanjut dapat dilihat pada Tabel 3. 
akan menyebabkan unsur hara yang terkandung di dalam tanaman tidak memberikan efek bagi pertumbuhan dan produksi tanaman. Pertumbuhan tinggi tanaman pada Tabel 1, dan bobot segar pertanaman pada Tabel 3 dibandingkan dengan deskripsi tanaman pakcoy sudah menyamai.

Tanaman yang sudah mendapatkan nutrisi yang sesuai kebutuhannya, maka tanaman tersebut akan tumbuh dengan baik. Menurut Novizan (2002), unsur hara yang didapatkan dari pemupukan akan memberikan efek fisiologis terhadap penyerapan unsur hara oleh perakaran tanaman sehingga pertumbuhan tanaman menjadi lebih baik. Hasil penelitian Sukasana et al. (2019), menunjukkan bahwa untuk memberikan pengaruh yang maksimal pada pertumbuhan budidaya tanaman pakcoy diperlukan konsentrasi sebesar $1250 \mathrm{ppm}$.

Unsur hara dapat diserap oleh tanaman dengan optimal disebabkan tingkat $\mathrm{pH}$ yang terlarut di dalam larutan nutrisi sudah dalam keadaan normal sehingga pertumbuhan tanaman berjalan dengan baik. Hal ini sesuai dengan Sutiyoso (2003), pH yang kurang dari 5,5 atau lebih dari 6,5 maka daya larut unsur hara tidak sempurna lagi, bahkan unsur hara mulai mengendap sehingga tidak bisa diserap oleh akar tanaman.

Nutrisi $A B$ mix mengandung 15 unsur hara esensial bagi tanaman untuk pertumbuhan dan perkembangan yang sehat bagi tanaman. Sutedjo (2010), menyatakan bahwa komposisi unsur hara makro maupun mikro sangat mempengaruhi pertumbuhan dan perkembangan tanaman. Unsur hara makro adalah unsur yang dibutuhkan dalam jumlah besar (0,1\%-5\%) yang meliputi $\mathrm{C}, \mathrm{H}, \mathrm{O}, \mathrm{N}, \mathrm{P}$, $\mathrm{K}, \mathrm{Mg}, \mathrm{Ca}$, dan $\mathrm{S}$. Sedangkan unsur hara mikro dibutuhkan dalam jumlah sedikit yakni kurang dari $0,025 \%$ yang meliputi Fe, Mn, B, Mo, Zn dan $\mathrm{Cu}$.

Unsur hara akan digunakan oleh tanaman untuk proses fotosintesis dan peningkatan proses metabolisme dalam tanaman yang akan mengakibatkan pembelahan sel. Pembelahan sel akan meningkatkan tinggi tanaman, jumlah daun (Tabel 1) dan luas daun, volume akar (Tabel 2) sehingga akan membuat berat tanaman, semakin meningkat juga (Tabel 3). Sarief (1985), menyatakan bahwa dengan tersedianya unsur hara dalam jumlah yang cukup pada saat pertumbuhan vegetatif, maka proses fotosintesis akan berjalan aktif sehingga proses pembelahan sel, perpanjangan dan diferensiasi sel akan berjalan dengan lancar pula.

Tanaman memanfaatkan unsur $\mathrm{N}$ untuk sintesis klorofil, asam amino dan protein sehingga mampu membentuk organ-organ tanaman. Nitrogen sebagai peyusun utama klorofil dan protein tanaman merupakan unsur yang mempunyai peran luas pada saat tanaman mengalami proses pertumbuhan vegetatif. Tisdale et al. ( 2003) menyatakan bahwa unsur $\mathrm{N}$ berperan penting dalam pembentukan zat hijau daun yang berguna sekali dalam proses fotosintesis. Nyakpa et al. (1986), menyatakan bahwa unsur $\mathrm{N}$ adalah penyusun utama biomassa tanaman muda dan berperan dalam meransang pertumbuhan vegetatif seperti meransang pertumbuhan daun, batang dan akar. Lahuddin (2007), menyatakan bahwa salah satu unsur hara yang berpengaruh terhadap pertumbuhan dan perkembangan tanaman adalah unsur $\mathrm{N}$.

Unsur fosfor $(\mathrm{P})$ merupakan salah satu unsur hara yang dapat menunjang perkembangan tanaman. Hal ini dikarenakan fosfor berperan dalam pembentukan inti sel serta pembelahan sel dan perbanyakan sel. Unsur fosfor dapat dikatakan sebagai titik tumbuh tanaman dalam pembentukan meristem yang selalu aktif membelah (sel) pada fase vegetatif tanaman, sehingga jaringan meristem akan menyokong pertumbuhan ke arah atas (meninggi) pada batang (Tabel 1) dan memanjang pada akar (Tabel 2), jaringan meristem juga menyokong pertumbuhan ke samping pada diameter batang sehingga memperberat tanaman atau meningkatnya berat segar tanaman (Tabel 3). Hardjowigeno (2003), menyatakan bahwa unsur fosfor sangat berguna untuk merangsang pertumbuhan akar, bahan dasar protein, proses fotosintesis, mempertebal batang tanaman serta membantu proses asimilasi dan respirasi.

Unsur hara $P$ juga berperan dalam penyusun RNA, DNA dan unit nukleotida lainnya sehingga dapat mempengaruhi pertumbuhan tanaman. Menurut Nyakpa et al. (1998), unsur hara $\mathrm{P}$ sangat berpengaruh terhadap pertumbuhan tanaman dikarenakan $\mathrm{P}$ banyak terdapat pada unit-unit nukleotida, RNA dan DNA yang berperan dalam pertumbuhan tanaman. Unsur $\mathrm{P}$ dalam menyimpan dan mentransfer energi tanaman memiliki energi adenosin trifosfat (ATP) yang terlibat semua aspek dalam pertumbuhan dan metabolisme khususnya saat terjadi proses 
fotosintesis tanaman. Serapan unsur $\mathrm{P}$ yang optimal bagi tanaman akan meningkatkan dan memperbanyak ATP pada tanaman. ATP berperan sebagai sumber energi pada reaksi gelap fotosintesis untuk menghasilkan glukosa sehingga dapat meningkatkan berat segar tanaman dan berat layak konsumsi tanaman yang ditunjukan pada Tabel 3. Sastrahidayat $e t$ al. (1999), menyatakan bahwa ATP dibutuhkan sebagai energi dalam pembelahan sel yang dapat meningkatkan hasil fotosintat tanaman.

Pada Tabel 3 menunjukkan bahwa bobot tanaman dapat tumbuh dengan baik, hal ini dikarenakan dalam meningkatkan pertumbuhan dan perkembangan tanaman, ketersediaan kalium (K) harus terpenuhi dengan cukup untuk mengaktifkan beberapa enzim pada proses fotosintesis. Unsur hara kalium berperan sebagai aktivator berbagai enzim. Aktivitas enzim-enzim dalam fotosintesis yang dimaksud seperti RuBP karboksilase, serta terlibat dalam sintesis ATP, penyerapan $\mathrm{CO}_{2}$ melalui mulut daun dan berperan dalam pembentukan jaringan penguat tanaman agar tanaman dapat berdiri kokoh dan tidak mudah roboh. Beberapa aktivitas enzim yang bekerja dengan baik membuat tanaman tidak mudah terserang hama dan penyakit. Sesuai yang diungkapkan Soepardi (1983), ketersediaan kalium yang cukup dapat menjamin ketegaran tanaman, sehingga membuat tanaman lebih tahan terhadap berbagai penyakit dan merangsang pertumbuhan akar.

Daun secara umum merupakan organ penghasil fotosintat utama. Luas daun (Tabel 2) akan berpengaruh terhadap seberapa banyak tanaman menerima sinar matahariyang digunakan untuk melakukan proses fotosintesis, semakin luas permukaan daun maka semakin banyak kloroplas pada tanaman dan banyak sinar matahari yang ditangkap. Sutedjo (2002), menyatakan bahwa unsur hara kalium mempengaruhi perkembangan jaringan meristem yang dapat mempengaruhi pertumbuhan daun. Kalium tersebut membantu memaksimlkan transportasi hasil fotosintesis dari daun menuju jaringan tanaman. Selanjutnya, hasil fotosintesis akan dirombak melalui proses respirasi yang akan menghasilkan energi untuk pembelahan dan pembesaran sel pada tubuh tanaman pakcoy sehingga pertumbuhan menjadi meningkat
Magnesium $(\mathrm{Mg})$ yang terdapat dalam nutrisi $\mathrm{AB}$ Mix merupakan salah satu unsur hara makro yang dibutuhkan oleh tanaman. Menurut Havlin et al. (2005), konsentrasi Magnesium $(\mathrm{Mg})$ di dalam tanaman beragam antara $0,1 \%$ dan $0,4 \%$. Magnesium dapat ditemukan diseluruh bagian tanaman terutama pada daun, karena $\mathrm{Mg}$ merupakan unsur utama penyusun klorofil.

Biswas et al. (2013), menyatakan bahwa Magnesium membantu menguatkan dinding sel dan meningkatkan serapan unsur hara makro lainnya seperti nitrogen, fosfor, dan sulfur tanaman. Unsur $\mathrm{Mg}$ di dalam tanaman menjadi komponen penting dalam penyusun molekul klorofil pada semua tanaman hijau sehingga peranannya tidak bisa digantiakan oleh unsur lain. Hal ini sependapat Tisdale dan Nelson (1975), unsur Mg merupakan satu-satunya unsur logam yang menyusun molekul klorofil. Peran $\mathrm{Mg}$ terlibat di seluruh metabolisme tanaman, dengan demikian ketersediaan $\mathrm{Mg}$ dalam jumlah besar dapat meningkatkan kehijauan daun, ketersediaan rubisco, penyerapan nitrogen, fiksasi $\mathrm{CO}_{2}$, oleh sebab itu peningkatan unsur $\mathrm{Mg}$ akan meningkatkan pertumbuhan jumlah daun pada Tabel 1 . Ketersediaan unsur Mg mempengaruhi kualitas proses fotosintesis dan bobot pertanaman pada Tabel 3. Menurut Marschner (2012), semakin tinggi kandungan $\mathrm{Mg}$ maka semakin banyak enzim rubisco yang mengikat karbon dalam proses asimilasi karbon sehingga meningkatkan laju fotosintesis dan pembentukan protein.

\section{KESIMPULAN}

\section{Kesimpulan}

Konsentrasi AB Mix yang diberikan mulai dari 1000, 1200, 1400, 1600 dan 1800 ppm berpengaruh tidak nyata untuk semua parameter yang diamati yaitu tinggi tanaman, jumlah daun, luas daun, volume akar, berat segar tanaman dan berat layak konsumsi. Pemberian konsentrasi AB Mix 1000 ppm merupakan konsentrasi terbaik dari beberapa konsentrasi yang diberikan disebabkan lebih efisien, ekonomis dan menghemat pemakaian larutan nutrisi.

\section{Saran}

Berdasarkan hasil penelitian yang telah dilakukan, untuk mendapatkan pertumbuhan dan hasil tanaman pakcoy putih yang baik dibudidayakan secara hidroponik dapat 
menggunakan konsentrasi nutrisi $\mathrm{AB}$ Mix 1000 ppm.

\section{DAFTAR PUSTAKA}

Biswas, H., S. M. Trivedi dan H. Chandrasekharan. 2010. Soil Fertility Capability Classification in a Semi-arid Region in Haryana with Special Reference to Soil Biological Condition Modifier. Journal of the Indian Society of Soil Science, 58 (4): 428-435.

Hardjowigeno, S. 1987. Klasifikasi Tanah dan Pedogenesis. Akademika Pressindo, Jakarta.

Havlin, J. L., J. D. Beaton, S. L. Nelson dan W. L. Nelson. 2005. Soil Fertility And Fertilizers. Pearson Prentice Hall, New Jersey.

Lahuddin, M. 2007. Aspek Unsur Mikro Dalam Kesuburan Tanah. USU Press, Medan.

Maghfoer, M. D., R. Soelistyono dan M. Ashrina. 2007. Pengaruh Tingkat Elektro-Konduktivitas dan Waktu Peningkatannya pada Pertumbuhan dan Hasil Tanaman Melon (Cucumis melo) Sistem Hidroponik Terapung. Jurnal Budidaya Pertanian Universitas Brawijaya, 29(3): 284-292.

Marschner, H. 1986. Mineral Nutrition of Higher Plant. Acaddemic Press, London.

Novizan. 2002. Petunjuk Pemupukan yang Efektif. Agromedia Pustaka, Jakarta.

Nugraha, R.U. 2014. Sumber Hara sebagai Pengganti AB MIX pada Budidaya Sayuran Daun Secara Hidroponik. Departemen Agronomi dan Hortikultura IPB, Bogor.

Nyakpa, M. Y., A. M. Lubis, M. A. Pulung, Amrah, A. Munawar, G. B. Hong dan N. Hakim. 1988. Kesuburan Tanah. Universitas Lampung Press, Lampung.

Rosmarkam, A. dan N. W Yuwono. 2001. Ilmu Kesuburan Tanah. Kanisius, Yogyakarta.

Sarief, E. S. 1985. Ilmu Tanah Pertanian. Pustaka Buana, Bandung.

Sastrahidayat, K., Wakidah, dan Syekfani. 1999. Pengaruh Mikoriza Vesikula Arbuskula terhadap Peningkatan Enzim Fosfatase, Beberapa Asam Organik dan Pertumbuhan Kapas (Gossypium hirsutum L.) pada Vertisol dan Alfizol.
Jurnal Agrivita Fakultas Pertanian Universitas Brawijaya, 21 (1): 10 - 19.

Soepardi, G. 1983. Sifat dan Ciri Tanah. Fakultas Pertanian Institut Pertanian Bogor, Bogor.

Sukasana, I., W. N. Karnata dan B. Irawan. 2019. Meningkatkan Pertumbuhan dan Hasil Pakcoy (Brassica juncearapal) dengan Mengatur Konsentrasi Nutrisi AB Mix Agrifarm dan Umur Bibit Secara Hidroponik Sistem NFT. Jurnal Agroteknologi Fakultas Pertanian Universitas Tabanan, 13(2): 212-220.

Sundari, R. Ince, dan S. H. Untung. 2016. Pengaruh POC dan AB Mix terhadap Pertumbuhan dan Hasil Tanaman Pakcoy (Brassica chinensis L.) dengan Sistem Hidroponik. Jurnal Agroteknologi Fakultas Pertanian Universitas Kutai Kartanegara, 16(2): 919.

Sutedjo, M. M. 2010. Pupuk dan Cara Pemupukan. Rineka Cipta, Jakarta.

Sutiyoso, Y. 2003. Meramu Pupuk Hidroponik: Tanaman Sayuran, Tanaman Buah, Tanaman Bunga. Penebar Swadaya, Jakarta.

Tisdale, S. L. dan W. L. Nelson. 1975. Soil Fertility and Fertilizers. 3rd. McMilan Publishing Co, New York. 